\title{
Primeiro relato da mancha foliar de Epicoccum sorghinum em Khaya grandifoliola no estado de São Paulo
}

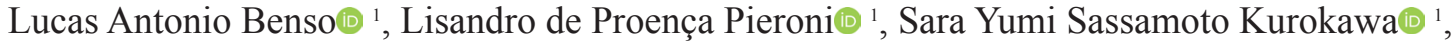 \\ Eduardo Silva Gorayeb®i] ', David Vitor dos Santos@ ', Cristiane de Pieri@ ', Edson Luiz Furtado@ 1
}

${ }^{1}$ Faculdade de Ciências Agronômicas - Universidade Estadual Paulista "Júlio de Mesquita Filho". Departamento de Proteção de Plantas. Av. Universitária, 3780, Altos do Paraíso, CEP: 18610-307, Botucatu, SP, Brasil.

Autor para correspondência: Lucas Antonio Benso (benso.florestal@gmail.com).

Data de chegada: 22/04/2019. Aceito para publicação em: 01/06/2020.

O gênero Khaya é formado por importantes espécies florestais conhecidas como mogno africano, que possuem madeira de coloração característica avermelhada, de densidade variada. A espécie Khaya grandifoliola C. DC. está entre as árvores de madeira nobre mais cultivadas no Brasil, sendo atualmente plantada em todas as regiões brasileiras $(1,2)$. Essa árvore, assim como qualquer outra cultura, é afetada por uma série de doenças. No ano de 2017, em um viveiro de mudas florestais no município de Garça/SP, foram observadas lesões foliares de formato irregular e coloração escura que incidiam esporadicamente em mudas sombreadas nas bordas do viveiro, em folhas jovens e adultas de $K$. grandifoliola. Devido à sombra, os locais onde essas mudas se encontravam apresentavam maior acúmulo de água na lona plástica que revestia o solo. Assim que observada a ocorrência da doença, plantas doentes foram encaminhadas ao Laboratório de Patologia Florestal na UNESP/Botucatu para identificação do agente causal. Desse material foram coletados fragmentos dos tecidos lesionados, passando em seguida pela esterilização superficial sequencial com álcool 70\%, hipoclorito de sódio $2 \%$ e água esterilizada, em torno de 1 minuto de imersão em cada solução. Por final, esses fragmentos foram plaqueados em placas de Petri contendo meio batatadextrose-ágar (BDA) e armazenados em câmara BOD à temperatura de $25{ }^{\circ} \mathrm{C}$ e fotoperíodo alternado ( 12 horas de luz e escuro). Sete dias após o plaqueamento, foi observada a formação de colônias fúngicas de coloração rosada, com pouco micélio aéreo e sem a formação de esporos sobre o meio de cultura. Dessas placas foram coletadas amostras de micélio por meio da raspagem superficial para realização da extração de DNA e posterior amplificação e sequenciamento da região ITS-5.8S rDNA (ITS 1 e 4). A sequência obtida foi postada no GenBank (Sequence ID: MK788189) e apresentou 99\% de similaridade com Epicoccum sorghinum (Sacc.) Aveskamp, Gruyter \& Verkley (sin. Phoma sorghina, Epicoccum sorghi) encontrado em grãos de sorgo (Sequence ID: MG969889.1) no Brasil. A comprovação da patogenicidade foi feita por meio da inoculação de folhas saudáveis de sete mudas de $K$. grandifoliola, com aproximadamente 5 meses de idade, através da deposição de discos com $5 \mathrm{~mm}$ de diâmetro de meio de cultura BDA contendo o fungo puro sobre os folíolos. Três outras mudas foram mantidas como testemunhas e receberam somente o meio de cultura livre de microrganismos. Todas as plantas foram mantidas em câmara úmida por $72 \mathrm{~h}$, em temperatura ambiente. Após esse tempo, observou-se a formação de lesões foliares semelhantes aquelas observadas nas mudas nas condições de viveiro. $\mathrm{O}$ fungo E. sorghinum foi reisolado com sucesso das folhas inoculadas com
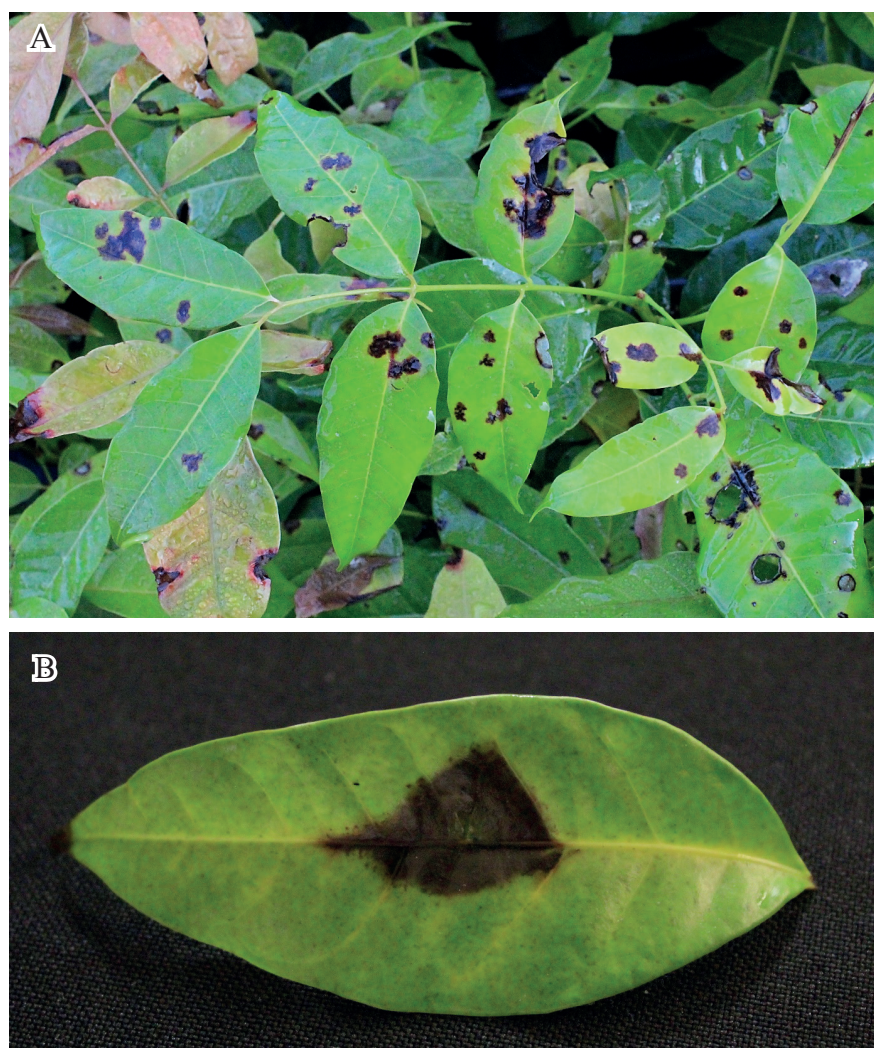

Figura 1. Sintomas de mancha foliar de Epicoccum sorghinum em folíolos de mudas enviveiradas de Khaya grandifoliola (A) e em folíolo inoculado com esse fungo (B).

o fungo, enquanto que nas testemunhas não ocorreu a formação de sintomas, comprovando assim a patogenicidade desse fungo em $K$. grandifoliola. Esse foi o primeiro relato dessa espécie florestal como hospedeira de E. sorghinum.

\section{REFERÊNCIAS}

1. Melo, J.E.; Carvalho, G.M.D; Martins, V.A. Espécies de madeiras substitutas do mogno. Brasília, DF: IBAMA, 1989. 16p.

2. Pinheiro, A.L.; Couto, L.; Pinheiro, D.T.; Brunetta, J.M.F.C. Ecologia, silvicultura e tecnologia de utilização dos mognos-africanos (Khaya spp.). Viçosa: Sociedade Brasileira de Agrossilvicultura, 2011. 102p. 